Article

\title{
Techno-Economic Evaluations of Copper-Based Chemical Looping Air Separation System for Oxy-Combustion and Gasification Power Plants with Carbon Capture
}

\author{
Calin-Cristian Cormos \\ Faculty of Chemistry and Chemical Engineering, Babes-Bolyai University, 11 Arany Janos Street, \\ RO-400028 Cluj-Napoca, Romania; cormos@chem.ubbcluj.ro; Tel.: +40-264-593833
}

Received: 11 October 2018; Accepted: 6 November 2018; Published: 9 November 2018

\begin{abstract}
Energy and economic penalties for $\mathrm{CO}_{2}$ capture are the main challenges in front of the carbon capture technologies. Chemical Looping Air Separation (CLAS) represents a potential solution for energy and cost-efficient oxygen production in comparison to the cryogenic method. This work is assessing the key techno-economic performances of a CLAS system using copper oxide as oxygen carrier integrated in coal and lignite-based oxy-combustion and gasification power plants. For comparison, similar combustion and gasification power plants using cryogenic air separation with and without carbon capture were considered as benchmark cases. The assessments were focused on large scale power plants with 350-500 MW net electricity output and $90 \% \mathrm{CO}_{2}$ capture rate. As the results show, the utilization of CLAS system in coal and lignite-based oxy-combustion and gasification power plants is improving the key techno-economic indicators e.g., increasing the energy efficiency by about $5-10 \%$, reduction of specific capital investments by about $12-18 \%$, lower cost of electricity by about $8-11 \%$ as well as lower $\mathrm{CO}_{2}$ avoidance cost by about $17-27 \%$. The highest techno-economic improvements being noticed for oxy-combustion cases since these plants are using more oxygen than gasification plants.
\end{abstract}

Keywords: chemical looping air separation (CLAS); techno-economic evaluation; oxy-fuel and gasification power plants; $\mathrm{CO}_{2}$ capture

\section{Introduction}

The need to minimize the anthropogenic $\mathrm{CO}_{2}$ emissions represents an important global aspect to be considered by any fossil fuel energy-intensive large-scale applications (energy generation, transportation, metallurgy, petro-chemistry, cement production etc.). There are several conceptual options to curb the fossil $\mathrm{CO}_{2}$ emissions, e.g., replacing fossil fuels with renewables (e.g., solar, wind, biomass), increasing energy efficiency of fuel conversion processes and most important the development and industrial deployment of Carbon Capture, Utilization and Storage (CCUS) technologies [1]. To acknowledge the importance of energy and reducing $\mathrm{CO}_{2}$ emissions, economic and legislative instruments are being put into practice to promote the reduction of anthropogenic greenhouse gas emissions (e.g., European Union climate and energy package [2]).

Regarding CCUS technologies, these methods will allow for continuing the usage of fossil fuels with reduced $\mathrm{CO}_{2}$ emissions. The main obstacles in large scale development of carbon capture technologies are representing the energy and cost penalties associated with $\mathrm{CO}_{2}$ capture [3-5]. Accordingly, significant research and development effort is directed to proposing innovative energy-efficient methods for $\mathrm{CO}_{2}$ capture. One group of innovative methods of $\mathrm{CO}_{2}$ capture with reduced energy and cost penalties is represented by chemical looping [6]. In such a technology, solid metallic oxides (acting as oxygen carriers) are used to transfer oxygen from air to the fossil fuel, 
in this way the nitrogen contamination of captured $\mathrm{CO}_{2}$ stream is prevented. There are various options for chemical looping technologies relating to the conversion of the fuel used e.g., chemical looping combustion (total oxidation) and chemical looping reforming (partial oxidation). The chemical looping technology can be used also for other potential important industrial applications e.g., hydrogen and oxygen production [7-9].

Regarding fuel conversion technologies, two options are particularly interesting in view of efficient fuel decarbonization: oxy-combustion and gasification. The oxy-combustion technology is promising as it has inherent in-situ $\mathrm{CO}_{2}$ capture (an oxygen-rich environment is used instead of air-avoiding complicate gas separation due to nitrogen dilution of the flue gases), increased energy efficiency and the potential retrofitting of combustion-based power plants $[10,11]$. The gasification technology is also promising as it provides potential for energy vectors poly-generation by syngas chemical processing, lower $\mathrm{CO}_{2}$ capture energy and cost penalties and increased energy efficiency [12,13]. In both oxy-combustion and gasification processes, one important ancillary energy consumer is represented by the Air Separation Unit (ASU). Conventionally at an industrial scale, cryogenic air separation (air liquefaction followed by distillation) is used as being a technology and commercially mature process [5]. The main drawback of cryogenic air separation is representing the power consumption of the ASU (about $200 \mathrm{kWh} / \mathrm{t}$ oxygen at a purity of $95 \%$ vol.).

Considering the elements presented above, this paper is aiming to investigate potential techno-economic benefits of an innovative looping cycle for air separation system (copper oxides were considered as oxygen carrier) in comparison to similar technologies with cryogenic air separation to be integrated in total oxidation (oxy-combustion) and partian oxidation (gasification) power plants. The proposed oxygen production based on copper oxides chemical looping cycle evaluated in this paper is based on the following reversible reaction [14]:

$$
4 \mathrm{CuO} \leftrightarrow 2 \mathrm{Cu}_{2} \mathrm{O}+\mathrm{O}_{2} \quad \Delta \mathrm{H}=263.2 \mathrm{~kJ} / \mathrm{molO}_{2}
$$

Figure 1 presents the conceptual design of chemical looping air separation system (CLAS) using copper oxides as oxygen carrier. The system consists of two reactors (mostly operated as interconnected fluidized beds but fixed and rotary bed arrangements can also be used [15]) in which one reactor is used for reduction of $\mathrm{CuO}$ to $\mathrm{Cu}_{2} \mathrm{O}$ (producing also oxygen) and the other reactor is used for solid $\left(\mathrm{Cu}_{2} \mathrm{O}\right)$ reoxidation. The solid flow circulating between the two reactors serves also to transfer heat from exothermic process $\left(\mathrm{Cu}_{2} \mathrm{O}\right.$ reoxidation) to the endothermic process ( $\mathrm{CuO}$ reduction). As fluidization media, steam is used in the $\mathrm{CuO}$ reduction reactor and air is used in the $\mathrm{Cu}_{2} \mathrm{O}$ reoxidation reactor. The gas stream from $\mathrm{CuO}$ reduction reactor (containing oxygen and steam) is cooled down generating steam (a part is reused in the reduction reactor), the condense removed and the oxygen can be used in further applications. A key element of this process is a tight thermal integration among various heat sources and sinks as presented in [16]. The CLAS system can use various other oxygen carriers such as $\mathrm{Mn}, \mathrm{Co}$-based materials but the copper system seems to be more promising in term of oxygen carrying capacity, operational conditions, overall energy efficiency and environmental impact $[17,18]$.

As key novelty aspects in comparison to the state of the art in the literature, this paper is evaluating the techno-economic aspects of an innovative industrial scale air separation system based on a copper looping cycle to be introduced in coal and lignite oxy-combustion and gasification power plants. As benchmark case for oxygen production, the cryogenic air separation was considered to quantify the differences in term of techno-economic performances. Both oxygen production processes were integrated into coal and lignite-based total oxidation (oxy-combustion) and partial oxidation (gasification) power plants with 350-500 MW net electricity output and $90 \% \mathrm{CO}_{2}$ capture rate. 


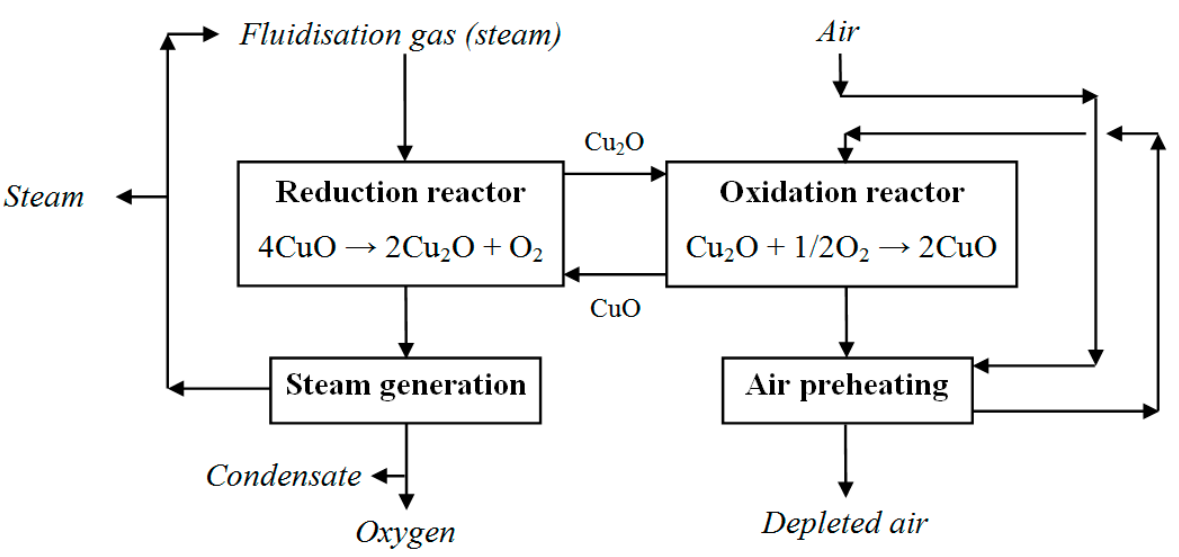

Figure 1. Design of copper-based chemical looping cycle used for oxygen production (CLAS).

\section{Assessing the Technical Performances of CLAS System Using Copper Oxides as Oxygen Carrier Integrated in Oxy-Combustion and Gasification Power Plants with Carbon Capture}

The technical performances of copper-based CLAS system integrated in coal and lignite oxy-combustion and integrated gasification combined cycle (IGCC) power plants equipped with carbon capture are assessed in this section. Figures 2 and 3 present the conceptual design of coal and lignite-based oxy-combustion and IGCC power plants suited with carbon capture. $\mathrm{CO}_{2}$ capture is done in oxy-combustion plants by flue gas cooling followed by condensate removal and in IGCC plants by pre-combustion capture using gas-liquid absorption (Selexol ${ }^{\mathrm{TM}}$ physical solvent was used). In both cases, captured $\mathrm{CO}_{2}$ is then conditioned (drying by tri-ethylene-glycol and then compressed to $120 \mathrm{bar}$ ).

The following coal and lignite power plant designs were evaluated in this paper to assess the main techno-economic and environmental indicators:

Case 1a: Super-critical pulverized coal (PC) power plant without $\mathrm{CO}_{2}$ capture;

Case 1b: Coal-based oxy-combustion power plant with cryogenic ASU and $\mathrm{CO}_{2}$ capture;

Case 1c: Coal-based oxy-combustion power plant with CLAS system and $\mathrm{CO}_{2}$ capture;

Case 1d: Lignite-based oxy-combustion power plant with cryogenic ASU and $\mathrm{CO}_{2}$ capture;

Case 1e: Lignite-based oxy-combustion power plant with CLAS system and $\mathrm{CO}_{2}$ capture;

Case 2a: Coal-based IGCC power plant with cryogenic ASU and without $\mathrm{CO}_{2}$ capture;

Case 2b: Coal-based IGCC power plant with cryogenic ASU and $\mathrm{CO}_{2}$ capture;

Case 2c: Coal-based IGCC power plant with CLAS system and $\mathrm{CO}_{2}$ capture;

Case 2d: Lignite-based IGCC power plant with cryogenic ASU and $\mathrm{CO}_{2}$ capture;

Case 2e: Lignite-based IGCC power plant with CLAS system and $\mathrm{CO}_{2}$ capture.

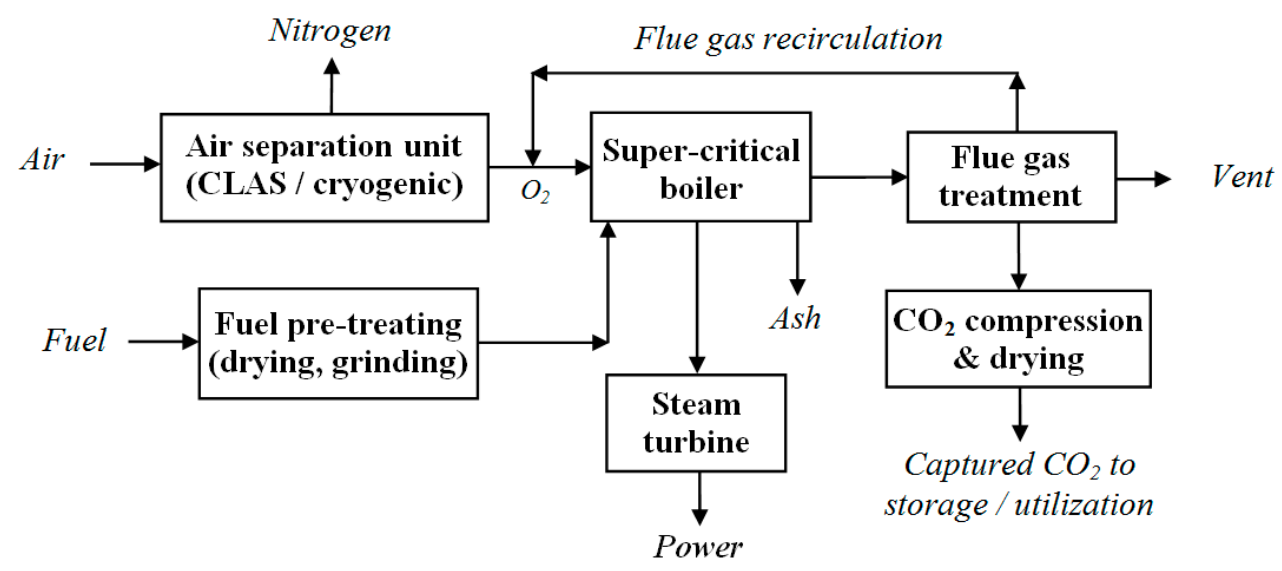

Figure 2. Design of oxy-fuel combustion power plant with $\mathrm{CO}_{2}$ capture. 
For comparison reasons, the benchmark cases using cryogenic air distillation as well-known method for oxygen production were considered to evaluate the potential advantages of copper-based chemical looping air separation system in terms of enhancing the key plant performance indicators. As base case without CCS for total oxidation (combustion) technology, a modern state of the art super-critical pulverized-coal power plant was evaluated (Case 1a). Also, other base cases with CCS were used to evaluate the potential advantages of CLAS systems within a low carbon scenario. For lignite cases, the fuel is dried to the final moisture of $10 \mathrm{wt} \%$ using energy-efficient fluidized bed with internal waste heat utilization process (WTA) developed by RWE Power, Germany [19].

The copper-based CLAS system as well as coal and lignite-based oxy-fuel and gasification power plants with carbon capture were simulated using a process flow modeling software (ChemCAD). The mass and energy balances produced by simulation were then used to quantify the performance indicators. As main design assumptions used to build the ChemCAD simulations, Table 1 presents the most important model assumptions [14,20-23]. Regarding the power block configurations and main parameters, the oxy-combustion concepts were evaluated considering the same super-critical steam conditions $\left(290 \mathrm{bar} / 582{ }^{\circ} \mathrm{C}\right.$ and two steam reheats at $75 \mathrm{bar} / 580^{\circ} \mathrm{C}$ and $20 \mathrm{bar} / 580^{\circ} \mathrm{C}$ ) in line with current technological development. The gasification concepts used a dry fed reactor (Shell gasification process and the same combined cycle gas turbine (CCGT) unit based on one Mitsubishi Hitachi Power Systems M701G2 gas turbine. For pre-combustion $\mathrm{CO}_{2}$ capture unit, Selexol ${ }^{\mathrm{TM}}$ process was chosen as acid gas removal system with separate $\mathrm{CO}_{2}$ and $\mathrm{H}_{2} \mathrm{~S}$ removal.

Regarding the chemical looping reactors configurations used in the CLAS system, the interconnected fluidized bed mode was chosen considering the available operating experience as well as the ease of operation considerations $[15,18]$. As the thermal operation mode of the chemical looping reactors, the adiabatic option was chosen considering that this is the simplest and most feasible thermal operation configuration. The ChemCAD flowsheets of the evaluated oxy-combustion and gasification power plant concepts are based on the conceptual designs presented in Figures 1-3.

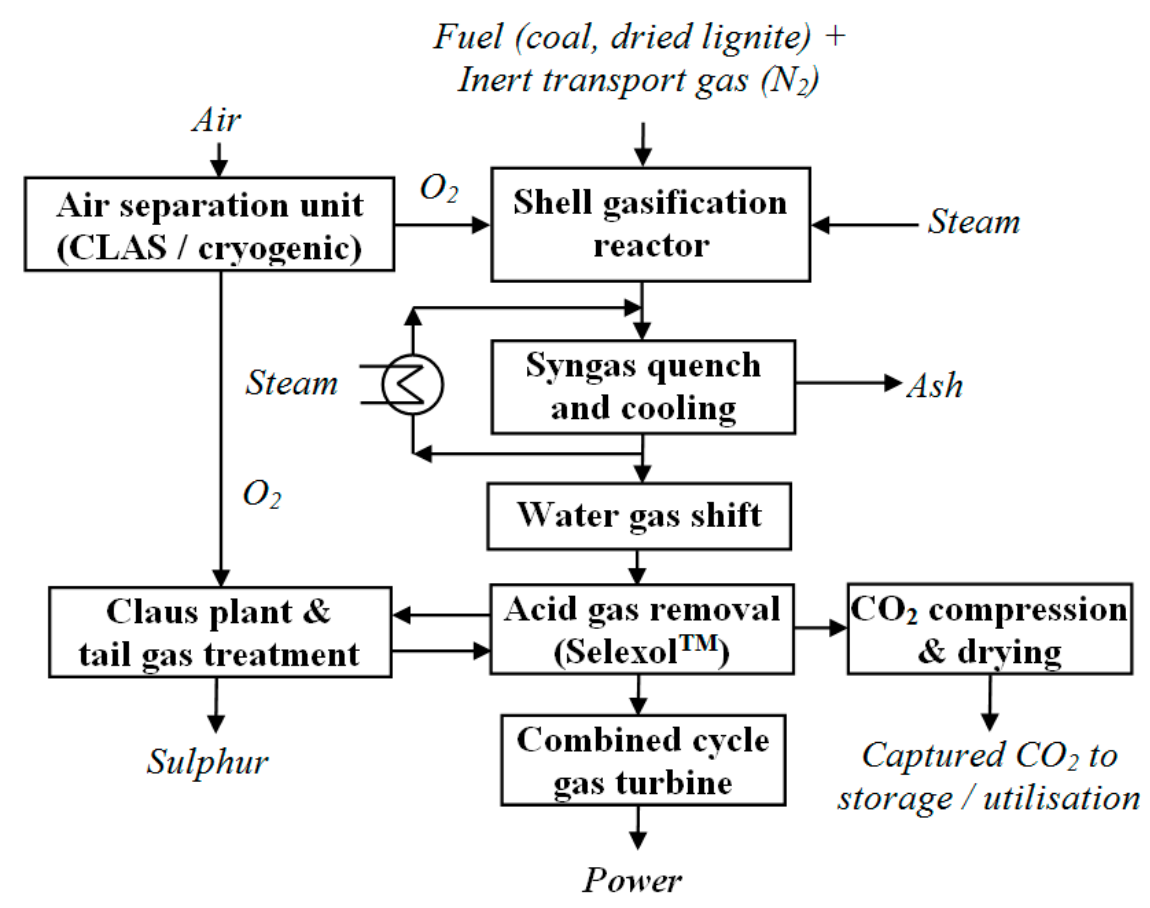

Figure 3. Design of integrated gasification combined cycle (IGCC) power plant suited with pre-combustion $\mathrm{CO}_{2}$ capture.

As mentioned before, the thermal integration of the heat sources and sinks (hot and cold process streams) within the CLAS system is crucial for an energy efficient process [24-26]. Pinch methodology 
was used to perform the thermal integration analysis not only for the CLAS system but also for the rest of the plant (a conservative value of $10{ }^{\circ} \mathrm{C}$ was chosen as minimum temperature difference). To illustrate the thermal integration analysis, Figure 4 presents the composite curves for the CLAS system used in conjunction with a coal-based super-critical oxy-combustion plant with carbon capture (Case 1c). The reason for the step-wise trends observed for HCC and CCC curves is the different number of hot and cold streams for each temperature interval.

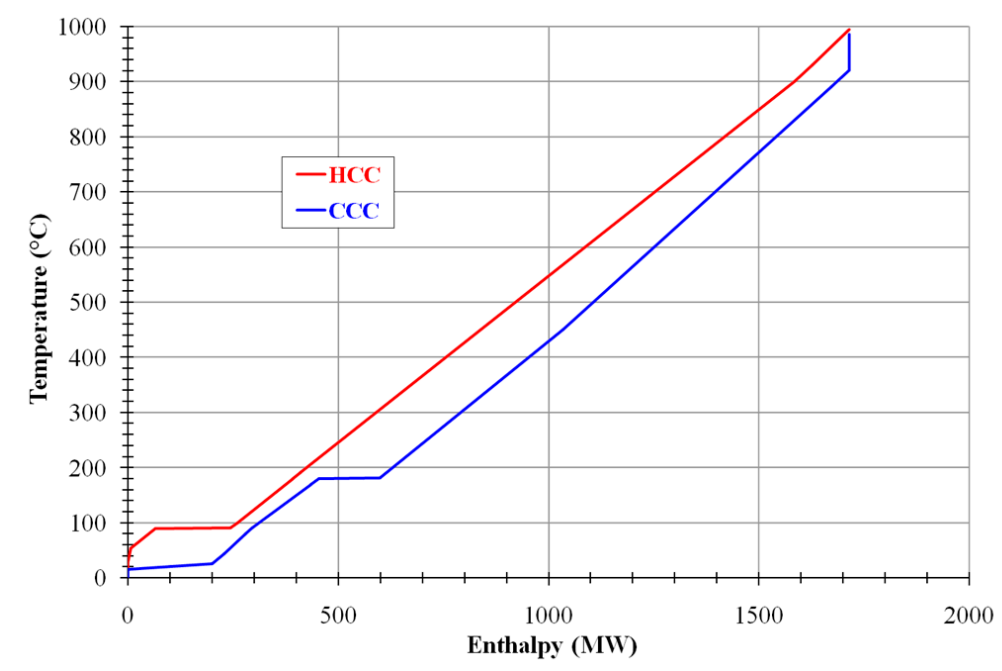

Figure 4. Hot and cold composite curves for CLAS system used in conjunction with Case 1c.

After the closed heat and power integration analysis, the power consumption of CLAS system was significantly reduced in comparison to the cryogenic process (66-68 vs. $200 \mathrm{kWh} / \mathrm{t}$ ) at similar purity of the produced oxygen ( $96 \%$ vs. $95 \%$ vol.). 
Table 1. Main model assumptions of evaluated oxy-combustion and gasification power plants integrated with copper-based CLAS system.

\begin{tabular}{|c|c|}
\hline Unit & Parameter \\
\hline Coal & $\begin{array}{l}\text { Elementary (ultimate) analysis (wt } \% \text { dry): } 72.31 \% \text { carbon, } 4.10 \% \text { hydrogen, } 1.69 \% \text { nitrogen } \\
7.45 \% \text { oxygen, } 0.56 \% \text { sulphur, } 13.89 \% \text { ash; Moisture: } 8 \% \text {; Lower calorific value: } 25.17 \mathrm{MJ} / \mathrm{kg}\end{array}$ \\
\hline Lignite & $\begin{array}{l}\text { Elementary (ultimate) analysis (wt } \% \text { dry): } 45.17 \% \text { carbon, } 3.64 \% \text { hydrogen, } 0.33 \% \text { nitrogen } \\
21.70 \% \text { oxygen, } 1.17 \% \text { sulphur, } 27.99 \% \text { ash; Moisture: } 40 \% \text {; Lower calorific value: } 15.03 \mathrm{MJ} / \mathrm{kg}\end{array}$ \\
\hline Fuel (lignite) drying & $\begin{array}{l}\text { Drying technology: Fluidized bed system with internal waste heat utilization-WTA } \\
\text { Final fuel moisture (after drying): } 10 \mathrm{wt} \text { \%; Power consumption: } 120 \mathrm{kWh} / \mathrm{t} \text { removed water }\end{array}$ \\
\hline Boiler (Cases 1a to 1e) & Super-critical pulverized coal (PC) boiler; Fuel conversion: $99.5 \%$ \\
\hline Gasification reactor (Cases 2a to 2e) & $\begin{array}{l}\text { Dry fed syngas quench reactor (Shell type) operated at } 40 \mathrm{bar} \text { and } 1400{ }^{\circ} \mathrm{C} \text {; Fuel conversion: } 99.5 \% \\
\text { Oxygen to coal ratio: } 0.84 \mathrm{~kg} / \mathrm{kg} \text {; Steam to coal ratio: } 0.12 \mathrm{~kg} / \mathrm{kg} \text {; Nitrogen to coal ratio: } 0.09 \mathrm{~kg} / \mathrm{kg} \\
\mathrm{O}_{2} \text { pressure fed to gasifier: } 48 \text { bar; Reactor pressure drop: } 1.5 \text { bar }\end{array}$ \\
\hline Cryogenic air separation unit & Oxygen purity: $95 \%$ (vol.); ASU electricity consumption: $200 \mathrm{kWh} / \mathrm{t}$ oxygen \\
\hline Copper-based chemical looping cycle as air separation unit & $\begin{array}{l}\text { Oxygen carrier: } \mathrm{CuO} / \mathrm{Cu}_{2} \mathrm{O}: \mathrm{TiO}_{2}=50: 50 \text { (weight basis) } \\
\text { Reduction reactor } \mathrm{T} \text { and p: } 900^{\circ} \mathrm{C} \text { and } 1.25 \text { bar; Reactor type: kinetic; Thermal operation: adiabatic } \\
\text { Oxidation reactor T and p: } 995^{\circ} \mathrm{C} \text { and } 1.25 \text { bar; Reactor type: kinetic; Thermal operation: adiabatic } \\
\text { Oxygen purity: } 96 \% \text { (vol.); Electricity consumption: } 66.1 \mathrm{kWh} / \mathrm{t} \text { oxygen; Steam consumption: } 0.84 \mathrm{t} / \mathrm{t}\end{array}$ \\
\hline Water gas shift stage (Cases 2a to 2e) & $\begin{array}{l}\text { Sour shift catalyst; Two water gas shift reactors (fixed bed); Steam/CO ratio: } 2 \\
\text { CO conversion: } 96-98 \% \text {; Reactor type: kinetic; Reactor thermal mode: adiabatic }\end{array}$ \\
\hline Desulphurization unit & $\begin{array}{l}\text { Cases 1a to 1e: Limestone FGD; } 98-99 \% \text { efficiency } \\
\text { Cases 2a to 2e: Selexol }{ }^{\mathrm{TM}} \text { acid gas removal system coupled with } \mathrm{O}_{2} \text {-blown Claus plant }\end{array}$ \\
\hline Carbon capture unit (Cases 2a to 2e) & $\begin{array}{l}\text { Selexol }{ }^{\mathrm{TM}} \text { acid gas removal system with separate } \mathrm{H}_{2} \mathrm{~S} \text { and } \mathrm{CO}_{2} \text { capture } \\
\text { Overall desulphurization yield: } \sim 99 \% \text {; Overall carbon capture yield: } \sim 95 \%\end{array}$ \\
\hline $\begin{array}{l}\text { Conditioning unit for captured } \mathrm{CO}_{2} \\
\text { (only for carbon capture designs) }\end{array}$ & $\begin{array}{l}\text { Four-stage compression with stage intercooling, Final delivery pressure: } 120 \text { bar } \\
\text { Captured } \mathrm{CO}_{2} \text { dehydration system: Tri-ethylene-glycol (TEG) } \\
\mathrm{CO}_{2} \text { quality specification (vol.\%): }>95 \% \mathrm{CO}_{2} ;<2000 \mathrm{ppm} \mathrm{CO} ;<250 \mathrm{ppm} \mathrm{H}_{2} \mathrm{O} ;<100 \mathrm{ppm} \mathrm{H}_{2} \mathrm{~S} \\
\left.<4 \% \text { non-condensable components (e.g., } \mathrm{H}_{2}, \mathrm{~N}_{2}, \mathrm{Ar}\right)\end{array}$ \\
\hline Power block & $\begin{array}{l}\text { Cases 1a to 1e: Steam turbine } \\
\text { Cases 2a to 2e: Gas turbine combined cycle; } 1 \times \text { M701G2 gas turbine } \\
\text { Net electricity output: } 334 \text { MW; Net power efficiency: } 39.5 \% \text {; Pressure ratio: } 21\end{array}$ \\
\hline Steam (Rankine) cycle & $\begin{array}{c}\text { Cases 1a to 1e: } 290 \text { bar } / 582^{\circ} \mathrm{C} \text {; Two reheats: } 75 \text { bar } / 580^{\circ} \mathrm{C} \text { and } 20 \text { bar } / 580^{\circ} \mathrm{C} \\
\text { Cases 2a to 2e: } 3 \text { steam pressure levels (HP: } 120 \text { bar MP: } 34 \text { bar LP: } 3 \text { bar); One MP reheat }\end{array}$ \\
\hline $\begin{array}{l}\text { Condenser pressure } \\
\text { Cooling water temperature } \\
\text { Heat exchanger } \Delta \mathrm{T}_{\min } \\
\text { Heat exchanger pressure drop }\end{array}$ & $\begin{array}{l}45 \mathrm{mbar} \\
15^{\circ} \mathrm{C} \\
10^{\circ} \mathrm{C} \\
1-3 \% \text { of inlet pressure }\end{array}$ \\
\hline
\end{tabular}


The key technical and environmental performances of coal and lignite combustion-based power plants are presented in Table 2. For all concepts, the fossil fuel thermal input is the same (about $1096 \mathrm{MW}_{\text {th }}$ ), the net electricity output is in the range of 353-475 MW. The net power efficiency for the non-capture design (benchmark design-Case 1a) is about $43.4 \%$ in line with the industrial experience $[21,27,28]$. The oxy-combustion cases with carbon capture have net efficiencies in the range of 32.2-37.8\% with an energy penalty for $\mathrm{CO}_{2}$ capture by about 5.6-11.2 net percentage points (the higher value being for lignite case with cryogenic air separation). One can notice also that the lignite cases have lower energy efficiencies compared to the coal cases by about 2.4-2.7 net percentage points due to lower fuel quality. The overall conclusion is that the CLAS concepts have superior efficiencies compared to cryogenic air separation cases by about 2.9-3.2 net percentage points for the same $\mathrm{CO}_{2}$ capture rate $(90 \%)$.

The key technical and environmental performances of coal and lignite gasification-based power plants are presented in Table 3. Considering that all investigated cases are using the same gas turbine, the fossil fuel thermal input is changing among various cases according to the overall plant energy efficiencies. The net electricity outputs of IGCC-based concepts are in the range of 382-484 MW. The net power efficiency for the benchmark case (non-capture design) is about $46 \%$ in accordance with the industrial experience for Shell gasification reactor [12,22,29-31]. IGCC power plants with carbon capture have net efficiencies in the range of 32-38.9\% with an energy penalty for $\mathrm{CO}_{2}$ capture by about 7.1-13.9 net percentage points (the higher value being for lignite case with cryogenic air separation). As in the case of oxy-combustion, the lignite-based IGCC cases have lower energy efficiencies compared to the coal cases by about 5.1 net percentage points due to lower fuel quality. Similar to oxy-combustion, the CLAS concepts used in conjunction with IGCC power plants exhibit superior efficiencies compared to cryogenic air separation cases by about 1.7 net percentage points for the same carbon capture rate (90\%). The smaller efficiency gain for IGCC compared is due to the fact that the gasification plants require lower oxygen demand that the oxy-combustion ones. 
Table 2. Overall coal and lignite oxy-combustion power plant technical performances.

\begin{tabular}{ccccccc}
\hline Main Plant Data & Units & Case 1a & Case 1b & Case 1c & Case 1d & Case 1e \\
\hline Coal/lignite flowrate & $\mathrm{t} / \mathrm{h}$ & 156.74 & 156.74 & 156.74 & 262.34 & 262.34 \\
Coal/lignite lower calorific value & $\mathrm{MJ} / \mathrm{kg}$ & & 25.17 & & \multicolumn{2}{c}{15.03} \\
Coal/lignite thermal energy (A) & $\mathrm{MW}$ th & 1095.87 & 1095.87 & 1095.87 & 1095.77 & 1095.77 \\
\hline Steam turbine output & $\mathrm{MW}_{\mathrm{e}}$ & 502.85 & 520.84 & 510.50 & 521.50 & 511.20 \\
Gross power output (B) & $\mathrm{MW}$ e & 502.85 & 520.84 & 510.50 & 521.50 & 511.20 \\
\hline Fuel processing & $\mathrm{MW}$ & 5.47 & 5.48 & 5.48 & 5.47 & 5.47 \\
Lignite drying (WTA process) & $\mathrm{MW}$ & 0.00 & 0.00 & 0.00 & 24.41 & 24.41 \\
Air separation unit & $\mathrm{MW}$ & 0.00 & 68.50 & 23.05 & 62.75 & 20.75 \\
$\mathrm{CO}_{2}$ capture and conditioning & $\mathrm{MW}$ & 0.00 & 52.70 & 52.65 & 60.35 & 60.40 \\
Power island power consumption & $\mathrm{MW}$ & 22.05 & 14.55 & 14.68 & 15.48 & 15.52 \\
Total ancillary power consumption (C) & $\mathrm{MW}$ & 27.52 & 141.23 & 95.86 & 168.46 & 126.55 \\
\hline Net power output $(\mathrm{D}=\mathrm{B}-\mathrm{C})$ & $\mathrm{MW}$ & 475.33 & 379.61 & 414.64 & 353.04 & 384.65 \\
Gross power efficiency (B/A $\times 100)$ & $\%$ & 45.88 & 47.52 & 46.58 & 47.59 & 46.65 \\
Net power efficiency (D/A $\times 100)$ & $\%$ & 43.37 & 34.64 & 37.83 & 32.21 & 35.10 \\
Carbon capture rate & $\%$ & 0.00 & 90.00 & 90.00 & 90.00 & 90.00 \\
$\mathrm{CO}_{2}$ specific emissions & $\mathrm{kg} / \mathrm{MWh}$ & 799.80 & 100.17 & 91.70 & 118.28 & 108.56 \\
\hline
\end{tabular}

Table 3. Overall coal and lignite IGCC power plant technical performances.

\begin{tabular}{|c|c|c|c|c|c|c|}
\hline Main Plant Data & Units & Case 2a & Case $2 b$ & Case 2c & Case 2d & Case $2 \mathrm{e}$ \\
\hline Coal/lignite flowrate & $t / h$ & 150.50 & 168.50 & 168.50 & 285.54 & 285.54 \\
\hline Coal/lignite lower calorific value & $\mathrm{MJ} / \mathrm{kg}$ & & 25.17 & & \multicolumn{2}{|c|}{15.03} \\
\hline Coal/lignite thermal energy (A) & $\mathrm{MW}_{\text {th }}$ & 1052.30 & 1178.10 & 1178.10 & 1192.71 & 1192.71 \\
\hline Gas turbine output & $\mathrm{MW}_{\mathrm{e}}$ & 334.00 & 334.00 & 334.00 & 334.00 & 334.00 \\
\hline Steam turbine output & $\mathrm{MW}_{\mathrm{e}}$ & 224.75 & 219.98 & 218.49 & 208.10 & 206.75 \\
\hline Expander power output & $\mathrm{MW}_{\mathrm{e}}$ & 1.35 & 0.50 & 0.50 & 0.75 & 0.75 \\
\hline Gross power output (B) & $\mathrm{MW}_{\mathrm{e}}$ & 560.10 & 554.48 & 552.99 & 542.85 & 541.50 \\
\hline Air separation including $\mathrm{O}_{2}$ compression & $\mathrm{MW}_{\mathrm{e}}$ & 41.85 & 47.32 & 25.14 & 46.49 & 24.01 \\
\hline Lignite drying (WTA process) & $\mathrm{MW}_{\mathrm{e}}$ & 0.00 & 0.00 & 0.00 & 19.23 & 19.23 \\
\hline Gasification island power consumption & $\mathrm{MW}_{\mathrm{e}}$ & 8.62 & 10.45 & 10.45 & 8.81 & 8.82 \\
\hline AGR including $\mathrm{CO}_{2}$ drying and compression & $\mathrm{MW}_{\mathrm{e}}$ & 6.70 & 39.62 & 39.65 & 67.78 & 67.75 \\
\hline Power island power consumption & $\mathrm{MW}_{\mathrm{e}}$ & 19.12 & 19.30 & 19.35 & 18.48 & 18.55 \\
\hline Total ancillary power consumption (C) & $\mathrm{MW}_{\mathrm{e}}$ & 76.29 & 116.69 & 94.59 & 160.79 & 138.36 \\
\hline Net power output $(D=B-C)$ & $\mathrm{MW}_{\mathrm{e}}$ & 483.81 & 437.78 & 458.40 & 382.06 & 403.14 \\
\hline Gross power efficiency $(\mathrm{B} / \mathrm{A} \times 100)$ & $\%$ & 53.22 & 47.06 & 46.93 & 45.51 & 45.40 \\
\hline Net power efficiency $(\mathrm{D} / \mathrm{A} \times 100)$ & $\%$ & 45.97 & 37.16 & 38.91 & 32.03 & 33.80 \\
\hline Carbon capture rate & $\%$ & 0.00 & 90.00 & 90.00 & 90.00 & 90.00 \\
\hline $\mathrm{CO}_{2}$ specific emissions & $\mathrm{kg} / \mathrm{MWh}$ & 760.12 & 86.25 & 82.37 & 98.52 & 92.52 \\
\hline
\end{tabular}


3. Assessing the Economic Performances of CLAS System Using Copper Oxides as Oxygen Carrier Integrated in Oxy-Combustion and Gasification Power Plants with Carbon Capture

As method used to estimate the capital costs of various investigated oxy-combustion and gasification power plant concepts, the cost correlation methodology was used [30]. For this purpose, the plant designs were split into main sub-systems e.g., solid fuel handling facilities, lignite drying unit, boiler/gasification island, air separation unit (either CLAS or cryogenic), flue gas/syngas treatment, $\mathrm{CO}_{2}$ capture and conditioning, sulphur removal unit, power block etc. The capital costs of each power plant sub-system were calculated using the following equation as presented in [32]:

$$
C_{E}=C_{B} \times\left(\frac{Q}{Q_{B}}\right)^{M} \times f_{M} \times f_{T} \times f_{P}
$$

where:

$C_{E}$ - equipment cost having capacity $Q$;

$C_{B}$-base cost for equipment having capacity $Q_{B}$;

$M$-constant (equipment type dependent);

$f_{M}, f_{T}, f_{P}$-correction factors for material of construction, temperature and pressure.

As scaling parameters for production capacity $(Q)$ in Equation (2), the main mass or energy streams processed by each plant sub-system were used. The production capacities $(Q)$ for each plant sub-system are based on the mass and energy balances obtained by simulation of various investigated oxy-combustion and gasification power plant designs. Reference base cost data $\left(C_{B}, Q_{B}\right.$ and $\left.M\right)$ used in the analysis are indexed on year 2018 (using Chemical Engineering Plant Cost Index-CEPCI) considering the values presented in literature $[11,22,30]$. The specific capital investment $(S C I)$ costs were assessed considering the total investment cost and net generated power for each power plant designs with the following equation:

$$
\text { SCI perkW(net })=\frac{\text { Total investment } \cos t}{\text { Net power output }}
$$

As the main economic assumptions used in capital cost calculation, the costs of external utilities and offsite units were evaluated as $25 \%$ of the plant sub-systems (on-site units). Owner's cost and contingency were estimated as $15 \%$ of the total installed cost. The costs related to land purchase, permitting, surveying etc. were estimated as $5 \%$ of the total installed cost [30]. Figure $5 \mathrm{a}, \mathrm{b}$ present the specific investment cost per $\mathrm{kW}$ net power, Figure $5 \mathrm{a}$ for coal and lignite oxy-combustion plant concepts and Figure $5 \mathrm{~b}$ for coal and lignite IGCC plant concepts. 


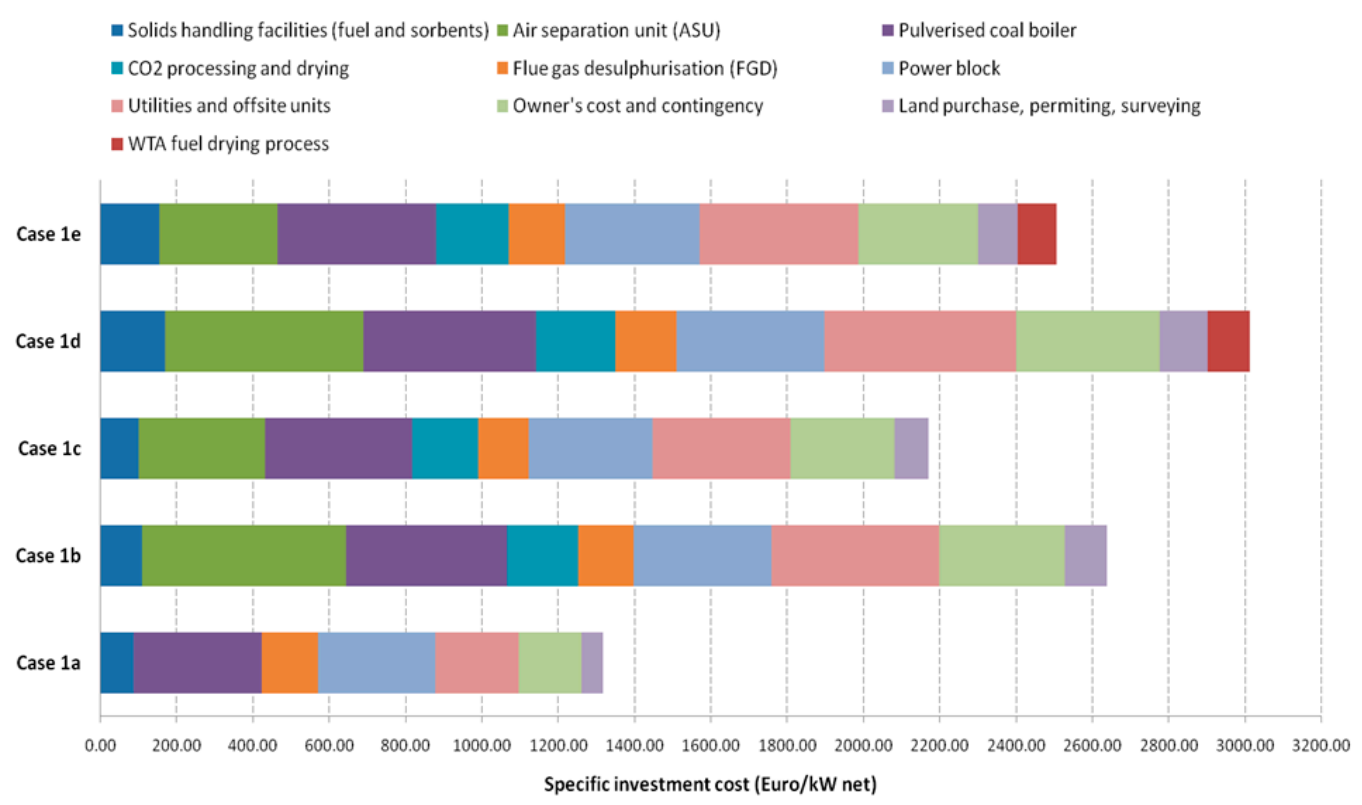

(a) Specific capital investment costs for coal and lignite oxy-combustion power plants.

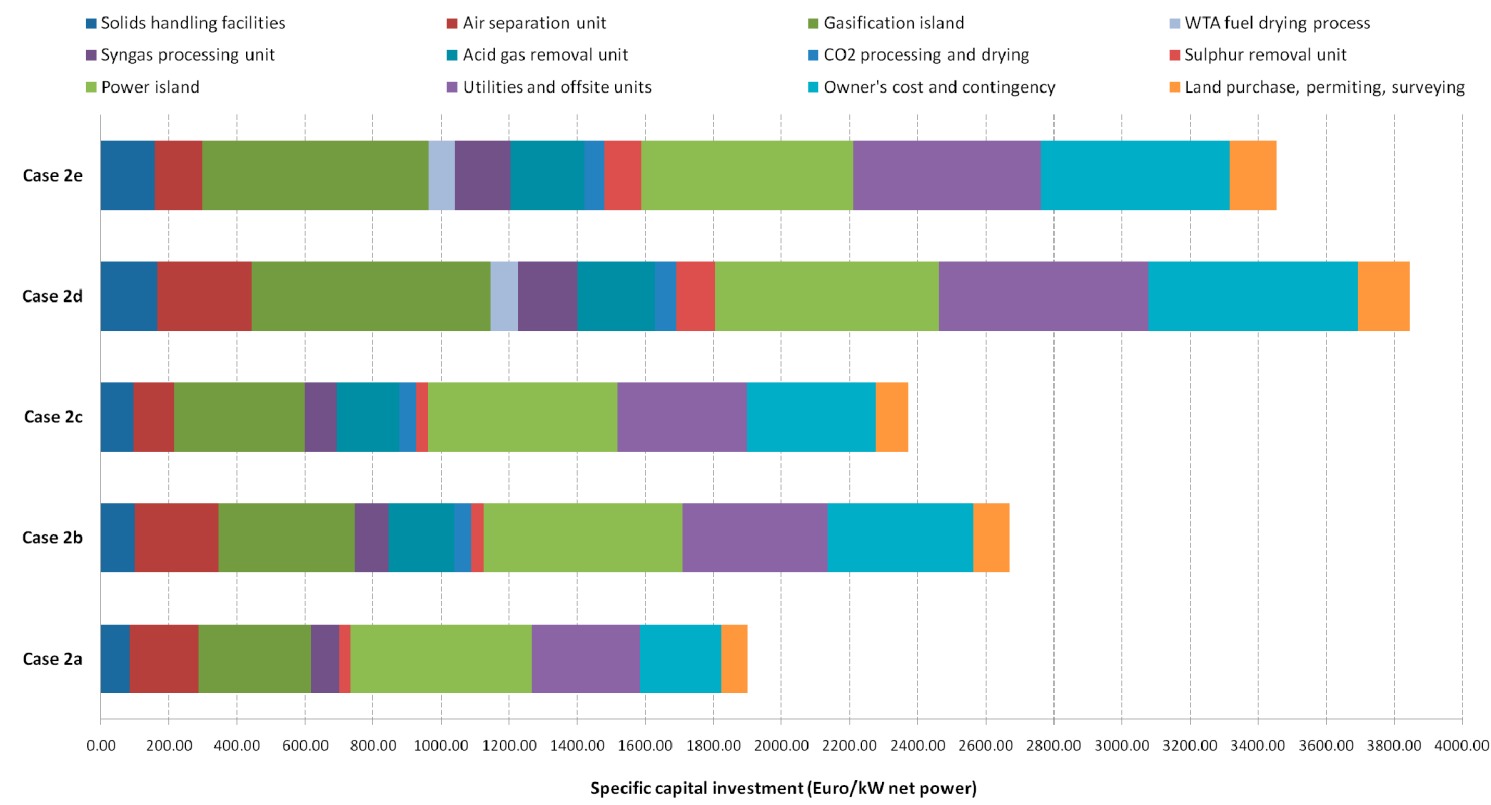

(b) Specific capital investment costs for coal and lignite gasification power plants.

Figure 5. Specific capital investment costs for oxy-combustion and gasification power plants.

As can be noticed from Figure $5 \mathrm{a}$, the specific investment costs for super-critical oxy-combustion power plants varied in the range between 1320 and $3010 € / \mathrm{kW}$ net power, the lowest value being for the super-critical pulverized coal (PC) plant concept without carbon capture (Case 1a) considered as benchmark case. The carbon capture concepts have significantly higher specific capital investment costs compared to the design without carbon capture by about $855-1700 € / \mathrm{kW}$ net power due to additional plant sub-systems (e.g., $\mathrm{CO}_{2}$ capture and conditioning) as well as lower overall plant energy efficiency. The CLAS concepts have lower specific investment costs than the cryogenic air separation concepts by about $470-510 € / \mathrm{kW}$ net power (the lower value being for coal and the higher one for lignite). When comparing different fuels, the coal designs have lower specific investment that the lignite ones by about $335-375 € / \mathrm{kW}$ net power. 
For IGCC power plants, the trends observed for oxy-combustion concepts are similar with the difference that the overall specific capital investment costs are higher due to a more complex plant design. The SCI costs varied in the range between 1900 and $3850 € / \mathrm{kW}$ net power, the lowest value being for the IGCC plant without carbon capture (Case 2a) considered as benchmark case. The carbon capture concepts have significantly higher specific capital investment costs compared to the design without carbon capture by about $470-1940 € / \mathrm{kW}$ net power. The CLAS concepts have lower specific investment costs than the cryogenic air separation concepts by about $300-395 € / \mathrm{kW}$ net power (the lower value being for coal and the higher one for lignite). One can notice that the specific investment cost gain for CLAS system used in an IGCC plant is lower than for an oxy-combustion plant because of lower oxygen demand. The coal designs have lower specific investment that the lignite ones by about $1100 € / \mathrm{kW}$ net power (significantly higher than for oxy-combustion designs).

Operational and maintenance (O\&M) costs have two main components: the fixed costs (which are independent of electricity output covering equipment depreciation, taxes, insurances, plant administration, annual overhaul etc.) and the variable costs (which are proportional to generated electricity covering fuel and other consumables, chemicals, catalysts, oxygen carrier, waste disposal, unscheduled repairs etc.). Table 4 presents the key assumptions used to assess the O\&M costs. The O\&M costs were evaluated using Peters and Timmerhaus method [33] considering all consumables in the process (based on mass and energy balances derived from simulation), personal and maintenance costs and the main economic assumptions presented in Table 4.

Table 4. Economic assumptions used for assessment of O\&M costs.

\begin{tabular}{cc}
\hline Parameter & Value \\
\hline Coal and lignite price & $2.5 € / \mathrm{GJ}$ \\
Auxiliary fuel (for IGCC cases) price & $6.0 € / \mathrm{GJ}$ \\
Limestone (fluxing material) price & $20 € / \mathrm{t}$ \\
Sulphur (by-product) price & $100 € / \mathrm{t}$ \\
Boiler fed water and process water price & $0.10 € / \mathrm{t}$ \\
Cooling water price & $0.01 € / \mathrm{t}$ \\
Catalysts (WGS, Claus) cost per year & $1,500,000 €$ \\
Selexol ${ }^{\mathrm{TM}}$ solvent price & $6500 € / \mathrm{t}$ \\
Copper oxide price & $1000 € / \mathrm{t}$ \\
CW chemical treatment & $0.0025 € / \mathrm{m}^{3}$ \\
Slag (ash) disposal price & $90,000 € / \mathrm{month}$ \\
Boiler fed water and process water treatment & $10.0 € / \mathrm{t}$ \\
Direct labor (number of plant personnel) & 105 persons $(\mathrm{oxy}-\mathrm{combustion})$ \\
Direct labor cost per year & 120 persons $(\mathrm{IGCC})$ \\
Administrative, support and overhead cost & $50,000 € / \mathrm{person}$ \\
Maintenance costs per year & $30 \%$ from direct labor cost \\
Working capital & $3.5 \%$ from capital costs \\
Average annual operational hours & 30 days plant supply \\
Discount rate & $7500 \mathrm{~h} /$ year \\
CO price $_{\text {price }}$ & $8 \%$ \\
Economic plant life & $5 € / \mathrm{t}$ \\
Plant construction time/capital share per year & 3 years $/ 40 \% ; 40 \% ; 20 \%$ \\
\hline
\end{tabular}

Once calculated the capital and operational and maintenance (O\&M) costs, the levelised cost of electricity (LCOE) for various investigated cases were calculated using the net present value (NPV) methodology as presented in [32]. The $\mathrm{CO}_{2}$ removal and avoidance costs (useful economic indicators when different energy conversion systems equiped with CCS are compared one to another) were calculated as follow:

$$
\mathrm{CO}_{2} \text { removal } \cos t=\frac{L C O E_{\text {Capture }}-L C O E_{\text {No capture }}}{\mathrm{CO}_{2} \text { removed }}
$$




$$
\mathrm{CO}_{2} \text { avoided } \cos t=\frac{\text { LCOE }_{\text {Capture }}-\text { LCOE }_{\text {No capture }}}{\text { Specific } \mathrm{CO}_{2} \text { emissions }_{\text {No capture }}-\text { Specific } \mathrm{CO}_{2} \text { emissions } \text { Capture }_{\text {emiste }}}
$$

For super-critical oxy-combustion power plants, the operation and maintenance (O\&M) costs, $\mathrm{CO}_{2}$ capture costs and levelized cost of electricity are presented in Table 5 . One can notice that the O\&M costs are higher for carbon capture designs (Cases $1 \mathrm{~b}$ to $1 \mathrm{e}$ ) than the benchmark case without carbon capture by about 34-45\%. The lignite-based cases have higher O\&M costs than the coal-based cases by about 4-6\% (due to lower fuel quality—see the carbon contents and calorific values of both fuels presented in Table 1). When compared the two evaluated oxygen production technologies, one can notice that both technologies exhibit similar O\&M costs (with a lower values for CLAS systems). Regarding the cost of electricity, it can be observed that there is a significant economic penalty between the carbon capture cases and the benchmark case without $\mathrm{CO}_{2}$ capture (about 55-102\% increase for CCS cases). Also, one can noticed that the difference between the two oxygen production technologies is widening in terms of cost of electricity (about 12\%). This fact is mainly due to the capital costs influence which is higher for the cryogenic air separation than for CLAS system.

For IGCC power plants, the operation and maintenance (O\&M) costs, $\mathrm{CO}_{2}$ capture costs and levelized cost of electricity are presented in Table 6. The trends of economic indicators for IGCC power plants are similar to the ones for the oxy-combustion power plants e.g., the CLAS system showed better economic performances than the cryogenic air separation system as oxygen production method, the lignite-based systems have higher costs than the coal-based systems etc. However, the differences between cryogenic air separation and CLAS system both used for IGCC power plants are smaller than for oxy-combustion power plants because of lower oxygen consumption. 
Table 5. Operation and maintenance (O\&M) costs, $\mathrm{CO}_{2}$ capture costs and levelized cost of electricity for oxy-combustion power plants.

\begin{tabular}{|c|c|c|c|c|c|c|}
\hline O\&M Costs & Units & Case 1a & Case $1 \mathrm{~b}$ & Case 1c & Case 1d & Case 1e \\
\hline \multicolumn{7}{|l|}{ Fixed O\&M costs } \\
\hline Annual maintenance cost & $\mathrm{M} € /$ year & 18.05 & 26.22 & 26.46 & 28.43 & 26.47 \\
\hline Direct labor cost & $\mathrm{M} € /$ year & 5.25 & 5.25 & 5.25 & 5.25 & 5.25 \\
\hline Administrative, support and overhead cost & $\mathrm{M} € /$ year & 1.58 & 1.58 & 1.58 & 1.58 & 1.58 \\
\hline Total fixed O\&M costs (year) & $\mathrm{M} € /$ year & 24.88 & 33.04 & 33.28 & 35.26 & 33.30 \\
\hline Total fixed O\&M costs (MWh net power) & $€ / \mathrm{MWh}$ & 6.97 & 11.60 & 10.70 & 13.31 & 11.54 \\
\hline \multicolumn{7}{|l|}{ Variable O\&M costs } \\
\hline Fuel & $\mathrm{M} € /$ year & 73.98 & 73.98 & 73.98 & 65.09 & 65.09 \\
\hline Make up water & $\mathrm{M} € /$ year & 0.08 & 0.17 & 0.16 & 2.76 & 2.76 \\
\hline Catalysts & $\mathrm{M} € /$ year & 0.50 & 0.50 & 0.50 & 0.50 & 0.50 \\
\hline Sorbent (limestone) and Oxygen carrier (copper oxide) & $\mathrm{M} € /$ year & 0.38 & 1.13 & 8.63 & 4.05 & 11.55 \\
\hline Chemicals & $\mathrm{M} € /$ year & 1.37 & 1.91 & 1.91 & 1.26 & 1.26 \\
\hline Total variable O\&M costs (year) & $\mathrm{M} € /$ year & 76.31 & 77.68 & 85.18 & 73.66 & 81.16 \\
\hline Total variable O\&M costs (MWh net power) & $€ / \mathrm{MWh}$ & 21.40 & 27.28 & 27.39 & 27.81 & 28.13 \\
\hline Total fixed and variable costs (year) & $\mathrm{M} € / \mathrm{y}$ & 101.19 & 110.72 & 118.46 & 108.92 & 114.46 \\
\hline Total fixed and variable costs (MWh net power) & $€ / \mathrm{MWh}$ & 28.38 & 38.89 & 38.09 & 41.13 & 39.67 \\
\hline Levelized cost of electricity (LCOE) & $€ / \mathrm{MWh}$ & 47.78 & 83.14 & 74.04 & 96.54 & 86.55 \\
\hline $\mathrm{CO}_{2}$ removal cost & $€ / \mathrm{t}$ & - & 39.21 & 31.80 & 45.80 & 39.66 \\
\hline $\mathrm{CO}_{2}$ avoided cost & $€ / t$ & - & 50.52 & 37.12 & 71.54 & 56.06 \\
\hline
\end{tabular}

Table 6. Operation and maintenance (O\&M) costs, $\mathrm{CO}_{2}$ capture costs and levelized cost of electricity for IGCC power plants.

\begin{tabular}{|c|c|c|c|c|c|c|}
\hline O\&M Costs & Units & Case 2a & Case $2 \mathrm{~b}$ & Case $2 \mathrm{c}$ & Case 2d & Case $2 \mathrm{e}$ \\
\hline \multicolumn{7}{|l|}{ Fixed O\&M costs } \\
\hline Annual maintenance cost & $\mathrm{M} € /$ year & 27.36 & 31.55 & 30.00 & 39.59 & 38.13 \\
\hline Direct labor cost & $\mathrm{M} € /$ year & 5.60 & 6.00 & 6.00 & 6.00 & 6.00 \\
\hline Administrative, support and overhead cost & $\mathrm{M} € /$ year & 1.68 & 1.80 & 1.80 & 1.80 & 1.80 \\
\hline Total fixed O\&M costs (year) & $\mathrm{M} € /$ year & 34.64 & 39.35 & 37.80 & 47.39 & 45.93 \\
\hline Total fixed O\&M costs (MWh net power) & $€ / \mathrm{MWh}$ & 9.54 & 11.98 & 10.99 & 16.53 & 15.19 \\
\hline \multicolumn{7}{|l|}{ Variable O\&M costs } \\
\hline Fuel & $\mathrm{M} € /$ year & 71.04 & 79.53 & 79.53 & 80.51 & 80.51 \\
\hline Auxiliary fuel & $\mathrm{M} € /$ year & 0.16 & 0.16 & 0.16 & 0.16 & 0.16 \\
\hline Make up water & $\mathrm{M} € /$ year & 0.07 & 0.28 & 0.28 & 0.29 & 0.29 \\
\hline Catalysts & $\mathrm{M} € /$ year & 0.00 & 1.50 & 1.50 & 1.50 & 1.50 \\
\hline Solvent (Selexol) and Oxygen carrier (copper oxide) & $\mathrm{M} € /$ year & 0.73 & 1.46 & 5.21 & 1.46 & 5.36 \\
\hline Chemicals & $\mathrm{M} € /$ year & 1.74 & 1.83 & 1.83 & 1.92 & 1.92 \\
\hline Waste disposal & $\mathrm{M} € /$ year & 1.49 & 1.62 & 1.62 & 1.49 & 1.49 \\
\hline Total variable O\&M costs (year) & $\mathrm{M} € /$ year & 75.22 & 86.38 & 90.13 & 87.32 & 91.22 \\
\hline Total variable O\&M costs (MWh net power) & $€ / \mathrm{MWh}$ & 20.72 & 26.30 & 26.21 & 30.47 & 30.17 \\
\hline & $\mathrm{M} € / \mathrm{y}$ & & 125.73 & 127.93 & 134.71 & 137.15 \\
\hline Total fixed and variable costs (MWh net power) & $€ / \mathrm{MWh}$ & 30.27 & 38.29 & 37.21 & 47.01 & 45.36 \\
\hline Levelized cost of electricity (LCOE) & $€ / \mathrm{MWh}$ & 57.76 & 81.01 & 74.86 & 100.77 & 99.98 \\
\hline $\mathrm{CO}_{2}$ removal cost & $€ / \mathrm{t}$ & - & 27.86 & 18.18 & 56.38 & 50.70 \\
\hline $\mathrm{CO}_{2}$ avoided cost & $\epsilon / t$ & - & 34.39 & 25.37 & 75.56 & 63.24 \\
\hline
\end{tabular}


To assess the variation of electricity cost vs. several key economic parameters (e.g., capital cost, coal and lignite costs, O\&M cost, interest rate, availability factor etc.), sensitivity analysis were performed. Figure $6 \mathrm{a}, \mathrm{b}$ present the variation of electricity cost with the capital cost $( \pm 10 \%$ variation scale), the fuel $\operatorname{cost}( \pm 10 \%$ variation scale), the O\&M cost $( \pm 10 \%$ variation scale), the interest rate ( $\pm 1 \%$ variation scale) and the plant availability factor ( $\pm 5 \%$ variation scale) for coal-based oxy-combustion and IGCC power plants equipped with CLAS system (Cases 1c and 2c).

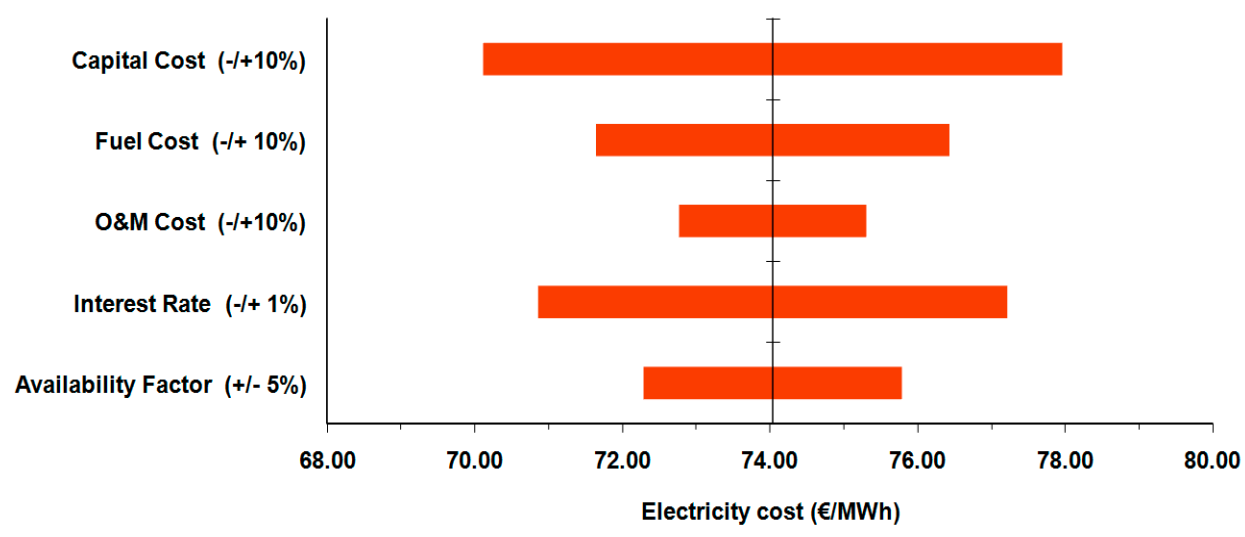

(a) Coal-based oxy-combustion power plant with CLAS system.

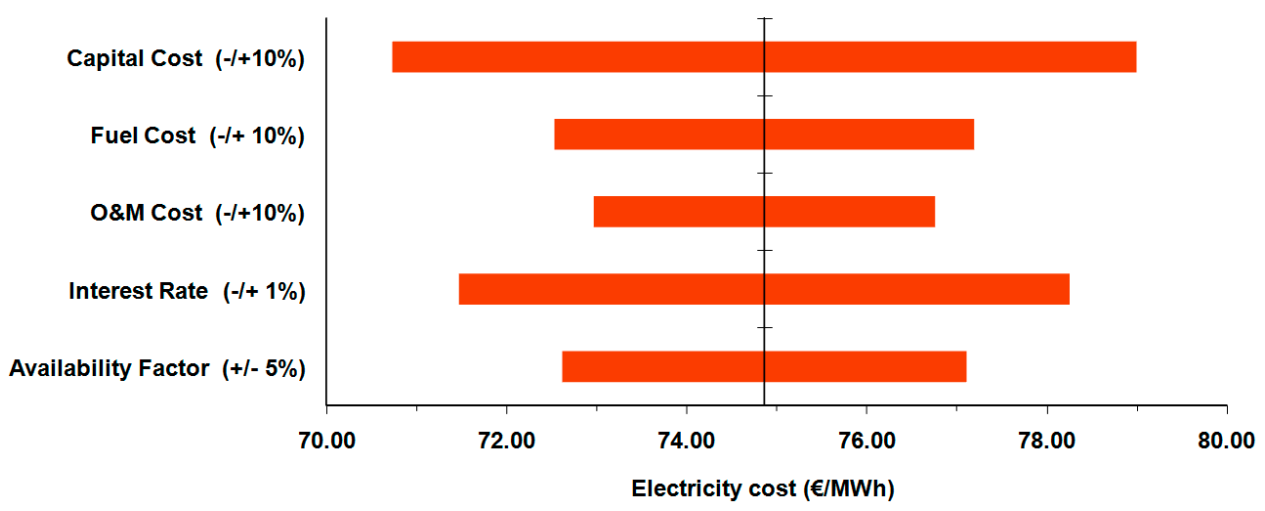

(b) Coal-based IGCC power plant with CLAS system (€/MWh).

Figure 6. Electricity cost sensitivity analysis for coal-based oxy-combustion and IGCC power plants equipped with CLAS system.

As can be noticed for both power generation technologies, the capital cost and the interest rate have the most pronounced influence on the electricity cost followed by the fuel cost and the plant availability factor. The O\&M cost has the smallest influence on the electricity cost.

Cash flow and cumulative cash flow are useful tools to assess the project economic over its entirely productive life [34]. As assumption used in the present analysis, 29 years was considered as whole project economic life divided as follow: 3 years for plant erection (40\%:40\%:20\% were considered as expenditure factors per each building year), 25 years for power plant operation and 1 year for recuperation of the working capital. The cumulative cash flow calculation was done in line with the proposed International Energy Agency-Greenhouse Gas Programme (IEAGHG) methodology [35]. The cumulative cash flows for assessed oxy-combustion and IGCC power plants are presented in Figure $7 \mathrm{a}, \mathrm{b}$. 


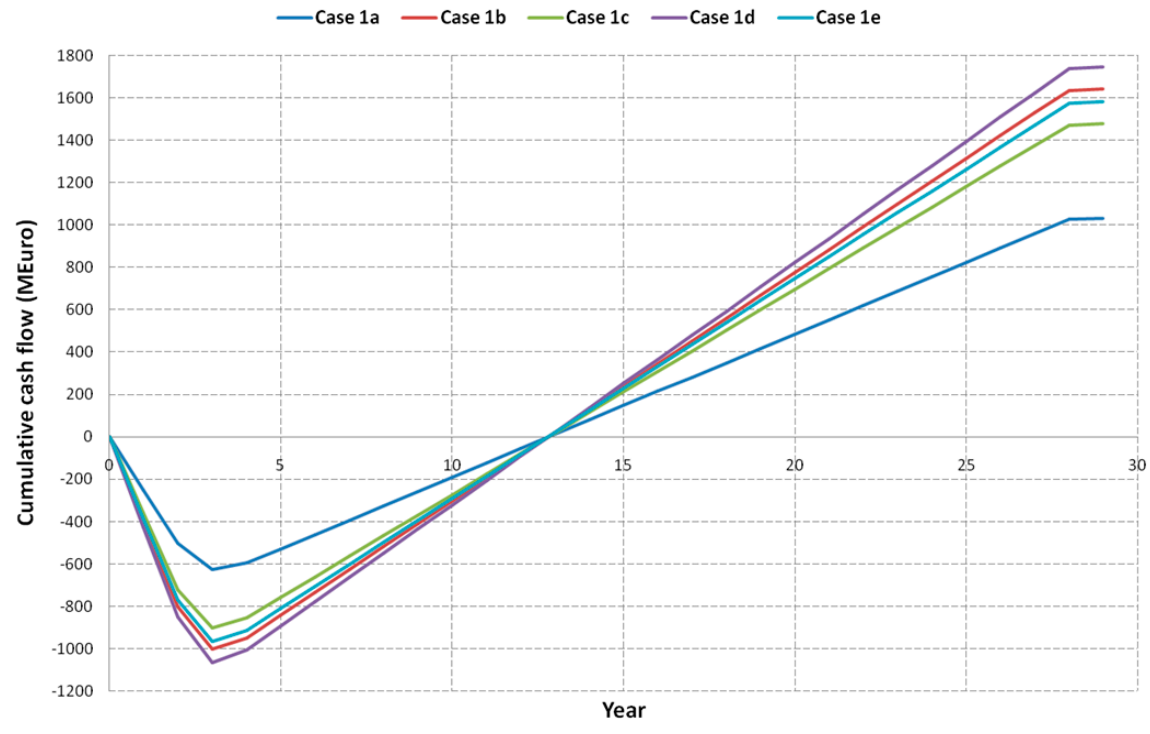

(a) Oxy-combustion power plants.

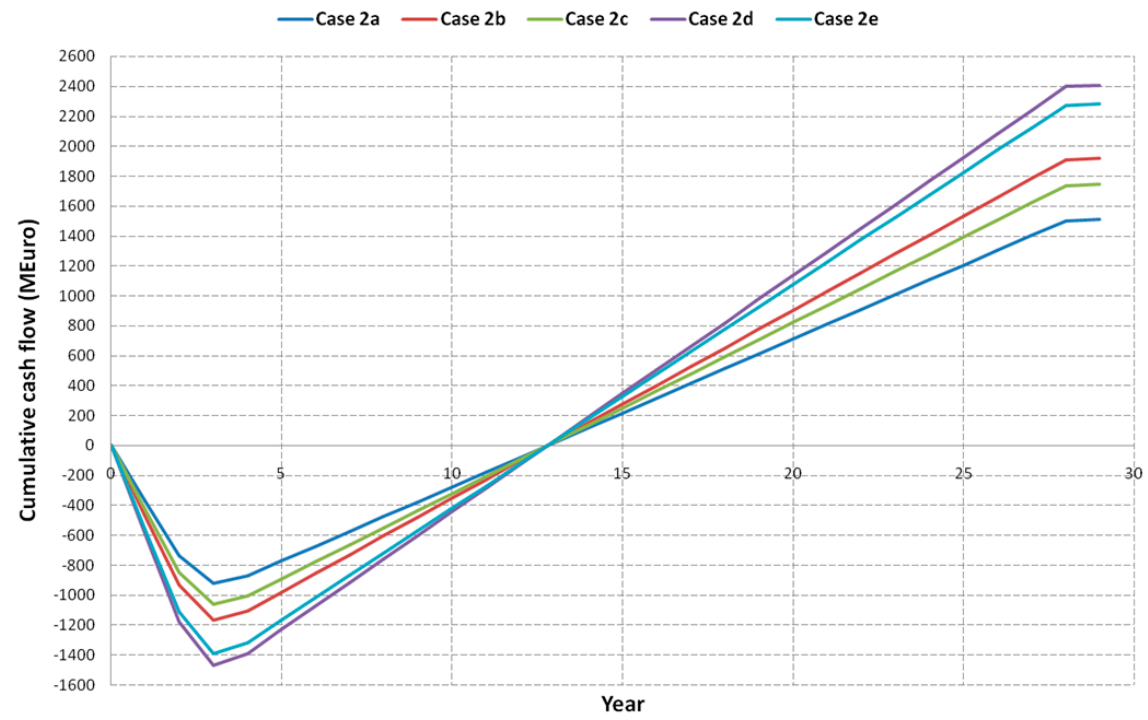

(b) IGCC power plants.

Figure 7. Cumulative cash flow analysis for oxy-combustion and IGCC power plants.

One can notice that for both power generation technologies the $\mathrm{CO}_{2}$ capture induces an increase of the overall cumulative cash flow compared to the designs without carbon capture. The payback period (for both oxy-combustion and gasification plants) is about 13 years. Also, it can be noticed that IGCC plants have higher cumulative cash flows than the oxy-combustion plants.

\section{Conclusions}

This paper assessed the main techno-economic and environmental performances of chemical looping air separation (CLAS) system used within coal and lignite-based oxy-combustion and gasification power plants. The assessments were concentrating on large scale power plants with 350-500 MW net electricity output and $90 \% \mathrm{CO}_{2}$ capture rate. Benchmark oxy-combustion and gasification cases without $\mathrm{CO}_{2}$ capture were examined to evaluate the potential energy efficiency refinements and to quantify the $\mathrm{CO}_{2}$ capture energy and cost penalties.

As the results demonstrate, the air separation systems based on chemical looping technology used in total oxidation (combustion) and partial oxidation (gasification) power plants confers significantly better techno-economic performances than the cryogenic air distillation. In terms of energy efficiency, 
the total oxidation (combustion) power plant equipped with CLAS system has net power efficiency with about 2.9-3.2 percentage points higher than the correspondent system with cryogenic air distillation. The partial oxidation (gasification) power plant equipped with CLAS technology has a net power efficiency with about 1.8 percentage points higher than the correspondent system with cryogenic air distillation. In terms of key economic indicators, the utilization of CLAS system in coal and lignite-based oxy-combustion and gasification power plants is significantly improves the economics e.g., reduction of specific capital investments by about $12-18 \%$ (e.g., from $2640-2670 € / \mathrm{kW}$ to about $2170-2370 € / \mathrm{kW}$ for coal oxy-combustion and gasification plants), lower cost of electricity by about 8-11\% (e.g., from $81-83.2 € /$ MWh to $74-75 € /$ MWh for coal oxy-combustion and gasification plants) as well as lower $\mathrm{CO}_{2}$ avoidance cost by about $17-27 \%$ (e.g., from $35-51 € / \mathrm{t}$ to $25-37 € / \mathrm{t}$ for coal oxy-combustion and gasification plants). The highest techno-economic improvements being noticed for oxy-combustion cases since these are using more oxygen than the gasification plants. The main conclusion of this work is that the chemical looping systems (illustrated here by copper-based cycle) are very promising for application in oxygen production used to significantly improve the overall energy efficiencies in comparison to current technology based on cryogenic air distillation.

Acknowledgments: This research was funded by a grant of the Romanian National Authority for Scientific Research, CNCS-UEFISCDI, project ID PN-III-P4-ID-PCE-2016-0031: “Developing innovative low carbon solutions for energy-intensive industrial applications by Carbon Capture, Utilization and Storage (CCUS) technologies".

Conflicts of Interest: The author declares no conflict of interest.

\section{References}

1. Metz, B.; Davidson, O.; de Coninck, H.; Loos, M.; Meyer, L. Carbon Dioxide Capture and Storage; Intergovernmental Panel on Climate Change (IPCC): Geneva, Switzerland, 2005; pp. 75-178. ISBN 13 978-0-521-68551-1.

2. European Commission. A policy framework for climate and energy in the period from 2020 to 2030. In Technical Report COM (2014); 15 final; Official Journal of the European Union: Brussels, Belgium, 2014.

3. Pettinau, A.; Ferrara, F.; Tola, V.; Cau, G. Techno-economic comparison between different technologies for $\mathrm{CO}_{2}$-free power generation from coal. Appl. Energy 2017, 193, 426-439. [CrossRef]

4. Lohwasser, R.; Madlener, R. Economics of CCS for coal plants: Impact of investment costs and efficiency on market diffusion in Europe. Energy Econ. 2012, 34, 850-863. [CrossRef]

5. Hanak, D.P.; Powell, D.; Manovic, V. Techno-economic analysis of oxy-combustion coal-fired power plant with cryogenic oxygen storage. Appl. Energy 2017, 191, 193-203. [CrossRef]

6. Fan, L.S. Chemical Looping Systems for Fossil Energy Conversions; Wiley-AIChE: Hoboken, NJ, USA, 2010; ISBN 978-0-470-87252-9.

7. Adanez, J.; Abad, A.; Garcia-Labiano, F.; Gayan, P.; de Diego, L.F. Progress in chemical-looping combustion and reforming technologies. Prog. Energy Combust. 2012, 38, 215-282. [CrossRef]

8. Luo, M.; Yi, Y.; Wang, S.; Wang, Z.; Du, M.; Pan, J.; Wang, Q. Review of hydrogen production using chemical-looping technology. Renew. Sust. Energy Rev. 2018, 81, 3186-3214. [CrossRef]

9. Shi, B.; $\mathrm{Wu}, \mathrm{E}$; $\mathrm{Wu}, \mathrm{W}$. Novel design of chemical looping air separation process for generating electricity and oxygen. Energy 2017, 134, 449-457. [CrossRef]

10. Skorek-Osikowska, A.; Bartela, L.; Kotowicz, J. A comparative thermodynamic, economic and risk analysis concerning implementation of oxy-combustion power plants integrated with cryogenic and hybrid air separation units. Energy Convers. Manag. 2015, 92, 421-430. [CrossRef]

11. Cormos, C.C. Oxy-combustion of coal, lignite and biomass: A techno-economic analysis for a large scale Carbon Capture and Storage (CCS) project in Romania. Fuel 2016, 169, 50-57. [CrossRef]

12. International Energy Agency-Greenhouse Gas R\&D Programme (IEAGHG). Potential for Improvement in Gasification Combined Cycle Power Generation with $\mathrm{CO}_{2}$ Capture; Report PH4/19; IEAGHG: Cheltenham, UK, 2003.

13. Parraga, J.; Khalilpour, K.R.; Vassallo, A. Polygeneration with biomass-integrated gasification combined cycle process: Review and prospective. Renew. Sustain. Energy Rev. 2018, 92, 219-234. [CrossRef]

14. Cormos, C.C. Assessment of copper-based chemical looping air separation system for energy efficiency improvements of oxy-combustion and gasification power plants. Appl. Therm. Eng. 2018, 130, 120-126. [CrossRef] 
15. Song, T.; Shen, L. Review of reactor for chemical looping combustion of solid fuels. Int. J. Greenh. Gas Control 2018, 76, 92-110. [CrossRef]

16. Moghtaderi, B. Application of chemical looping concept for air separation at high temperatures. Energy Fuel 2010, 24, 190-198. [CrossRef]

17. Shah, K.; Moghtaderi, B.; Wall, T. Selection of suitable oxygen carriers for chemical looping air separation: A thermodynamic approach. Energy Fuel 2012, 26, 2038-2045. [CrossRef]

18. Ghoniem, A.F.; Zhao, Z.; Dimitrakopoulos, G. Gas oxy combustion and conversion technologies for low carbon energy: Fundamentals, modeling and reactors. Proc. Combust. Inst. 2018. [CrossRef]

19. The WTA Technology—An Advanced Method of Processing and Drying Lignite. Available online: https:/ / www. rwe.com/web/cms/mediablob/en/2858/data/77254/2/rwe-power-ag/wta-plant/Download.pdf (accessed on 10 October 2018).

20. Zhu, L.; Wang, F.; Zhang, Z. Thermodynamic evaluation of a conceptual process for coal gasification coupled with chemical looping air separation. Chem. Eng. Process. 2016, 106, 33-41. [CrossRef]

21. Cormos, C.C. Chemical Looping with Oxygen Uncoupling (CLOU) concepts for high energy efficient power generation with near total fuel decarbonisation. Appl. Therm. Eng. 2016, 112, 924-931. [CrossRef]

22. Cormos, C.C. Integrated assessment of IGCC power generation technology with carbon capture and storage (CCS). Energy 2012, 42, 434-445. [CrossRef]

23. Deng, Z.; Jin, B.; Zhao, Y.; Gao, H.; Huang, Y.; Luo, X.; Liang, Z. Process simulation and thermodynamic evaluation for chemical looping air separation using fluidized bed reactors. Energy Convers. Manag. 2018, 160, 289-301. [CrossRef]

24. Bandyopadhyay, S.; Varghese, J.; Bansal, V. Targeting for cogeneration potential through total site integration. Appl. Therm. Eng. 2010, 30, 6-14. [CrossRef]

25. Cloete, S.; Giuffrida, A.; Romano, M.; Chiesa, P.; Pishahang, M.; Larring, Y. Integration of chemical looping oxygen production and chemical looping combustion in integrated gasification combined cycles. Fuel 2018, 220, 725-743. [CrossRef]

26. Shah, K.; Moghtaderi, B.; Zanganeh, J.; Wall, T. Integration options for novel chemical looping air separation (ICLAS) process for oxygen production in oxy-fuel coal fired power plants. Fuel 2013, 107, 356-370. [CrossRef]

27. Department of Energy -National Energy Technology Laboratory (NETL). Cost and Performance Baseline for Fossil Energy Plants. Volume 1: Bituminous Coal and Natural Gas to Electricity; Report DOE/NETL-2010/1397; NETL: Pittsburgh, PA, USA, 2010.

28. International Energy Agency-Greenhouse Gas R\&D Programme (IEAGHG). CO 2 Capture in Low Rank Coal Power Plants; Report 2006/1; IEAGHG: Cheltenham, UK, 2006.

29. Higman, C.; van der Burgt, M. Gasification, 2nd ed.; Gulf Professional Publishing: Houston, TX, USA, 2008; ISBN 9780750685283.

30. Cormos, C.C.; Vatopoulos, K.; Tzimas, E. Assessment of the consumption of water and construction materials in state-of-the-art fossil fuel power generation technologies involving $\mathrm{CO}_{2}$ capture. Energy 2013, 51, 37-49. [CrossRef]

31. Cloete, S.; Tobiesen, A.; Morud, J.; Romano, M.; Chiesa, P.; Giuffrida, A.; Larring, Y. Economic assessment of chemical looping oxygen production and chemical looping combustion in integrated gasification combined cycles. Int. J. Greenh. Gas Control 2018, 78, 354-363. [CrossRef]

32. Smith, R. Chemical Process Design and Integration, 2nd ed.; Wiley: Hoboken, NJ, USA, 2016; ISBN 978-1119990130.

33. Peters, M.S.; Timmerhaus, K.S. Plant Design and Economics for Chemical Engineers, 5th ed.; McGraw Hill: New York, NY, USA, 2002; ISBN 978-0072392661.

34. Towler, G.; Sinnott, R.K. Chemical Engineering Design: Principles, Practice and Economics of Plant and Process Design, 2nd ed.; Butterworth-Heinemann: Oxford, UK, 2012; ISBN 978-0080966595.

35. International Energy Agency-Greenhouse Gas R\&D Programme (IEAGHG). Co-Production of Hydrogen and Electricity by Coal Gasification with $\mathrm{CO}_{2}$ Capture-Updated Economic Analysis; Report 2008/9; IEAGHG: Cheltenham, UK, 2008.

(C) 2018 by the author. Licensee MDPI, Basel, Switzerland. This article is an open access article distributed under the terms and conditions of the Creative Commons Attribution (CC BY) license (http://creativecommons.org/licenses/by/4.0/). 